\title{
Designing Better Education in the Age of Globalization by Building Partnerships, Connecting People, and Promoting Innovation
}

\author{
Sudhir Mehta, Zhifeng Kou \\ North Dakota State University
}

\begin{abstract}
Several scholars, educators, and policy makers have noted that globalization is not just a passing phenomenon, but rather, the definitive world system. Universities and colleges in the $21 \mathrm{st}$ century will need to adopt an educational paradigm where interdependence and interconnectedness among the world's people become the norm. As Dwight D. Eisenhower said, "If people get together, so eventually will nations." Hence, it is necessary to increase international collaboration and activities that promote greater interactions among students, faculty, and industries from different nations.

This paper provides details of a new project that has been started at North Dakota State University (NDSU) to promote international collaboration and activities. In the future, NDSU plans to expand the number of disciplines and also open off-campuses in India, Dubai, and other countries. Industrial partnerships are an important part of this project. An industrial advisory board has been set-up for the NDSU-India project, and senior officials from 3M, General Motors (GM), John Deere, and Microsoft have already agreed to serve on the board. Such partnerships can prove beneficial to everyone involved and to the global society as a whole.

Inspiration, innovation, empowerment, inquiry, and life-long learning should be an integral part of a curriculum design. Such pedagogies are absolutely essential in the global economy, because they prepare students who can start contributing quickly at their work places, as well as in society. One such program that has been initiated at NDSU is described below.
\end{abstract}

\section{Need for Bringing Global Perspectives in Higher Education}

The National Association of State Universities and Land-Grant Colleges (NASULGC) formed a task force of 20 scholars, educators, and policy makers, which included university presidents, chancellors, and provosts, to study an internationalization aspect of higher education. ${ }^{1}$ Its report has just been released and it notes:

Global leadership in higher education by American colleges and universities - a hallmark during the past century - is increasingly at risk, ironically by the very forces our institutions helped to create. Advances in technology and telecommunications and a remaking of the global economy have created a world 
in which interdisciplinary, cross-border research and discovery are the norm and expectations for students prepared to live, work, and contribute to an interconnected world are high. Institutions that are able to prepare students-of-theworld will be the colleges and universities of the next century.

\section{Poised for Leadership}

NASULGC's state universities and land-grant colleges are both eminently qualified and aptly poised to take a leadership role in creating the new global university. Our history of recreating ourselves to serve a changing society has prepared us to lead the next wave of change as well. To do so, however, will require determined and inspired leadership by presidents and chancellors, for the challenges are great. National security concerns are affecting our ability to keep our campuses open to international students and faculty exchanges. Educationabroad programs, while increasing in number, still involve only 3 percent of undergraduates annually. Only one in 10 American students studies a foreign language. The sad truth is that American campuses have failed to internationalize at the very time it is essential to serve our students, our communities and the world.

Four Good Reasons to Internationalize

The rationale for internationalization - and by that we mean integrating international perspectives and experiences into learning, discovery and engagement - has never been more urgent:

1. For our students internationalization helps them to develop the global critical thinking essential to contributing as citizens of the world and competing in the international marketplace.

2. For our communities internationalization links them to the world, expanding opportunities for university service and engagement while also enhancing their global competitiveness.

3. For our nation internationalization contributes to national security and a vital economy and prepares future world leaders who know and value American democracy.

4. For our institutions internationalization enlivens faculty scholarship and teaching, expands research opportunities, and provides a pathway to national and international distinction.

"Shared Futures: Global Learning and Social Responsibility" is a national initiative of The Association of American Colleges and Universities (AAC\&U). ${ }^{2}$ It assumes we live in an interdependent world and that higher education can help prepare students not only to thrive in such a world but also to remedy its inequities. In such a world, AAC\&U seeks to support the academy in its vital role of expanding knowledge about the world's people and problems and advancing democracy and justice both at home and abroad. In their report they note: 
The global forces shaping today's world are rapid and intense; they present both dazzling opportunities and unsettling dangers. Colleges and universities are expected to prepare students for the global world of work while also producing graduates who recognize their shared obligation to humanity as a whole, independent of nationality. To help create a blueprint for shared futures marked by justice, security, equality, human rights, and economic sustainability, students will require new knowledge, a high level of intellectual sophistication, significant adeptness with intercultural literacies, and morally grounded commitments to be engaged citizens in their local and global communities. AAC\&U believes they will be all the more effective if they are also skilled in the arts of inclusive democracy and infused with the ideals of liberal education.

Dr. Robert M. Gates, the president of Texas A\&M University, gave a presentation, "Open Doors Versus Closed Borders: The Challenge for Universities," at the convention of National Association of State Universities and Land-Grant Colleges on November 18, 2003. ${ }^{3}$ He notes:

Intercultural exchange of our students and faculty working with students and scholars from other lands, whether in the U.S. or in foreign countries, is essential to fostering better understanding and facilitating the core mission of land-grant universities and colleges in developing new knowledge and bringing that knowledge into use in society.

The war on terror will not be won in a single approach but in a multi-faceted manner that involves institutions of higher education as partners in building and maintaining the scientific and academic relationships for which we are so well known. However, to do so requires the continued commitment of the federal government to invest resources in international education and research activities.

\section{Guiding Principles for Developing International Programs at North Dakota State University*}

At North Dakota State University (NDSU), like at many other universities, the importance of internationalization of campus and curriculum is well recognized. NDSU has an office of international programs and includes a global perspective in its general education requirement. Recently, to enhance international collaborations, the following guiding principles have been proposed.

The international programs are desirable for a number of reasons:

- They help develop bilateral academic exchange relationships;

- They promote understanding of each other's culture;

- They facilitate interdependence and interconnectedness among the world's people;

- They contribute to the overall internationalization of the campus;

- They contribute to increasing high-quality international student enrollments;

- They enhance the development of international alumni relations;

- They allow access to US education in other countries at an affordable cost;

- They raise the international profile and prestige of the University. 
The following basic principles must be met for developing international off-campus sites or course locations:

a) the proposed program must be consistent with institutional mission, vision, and priorities;

b) the proposed program must meet accreditation requirements of the University, and, if applicable, of the degree program;

c) the programs which will offer NDSU credit must adhere to the University's established standards in effect for similar programs on the home campus;

d) the international partner must be an institution of higher education recognized by the appropriate authority in the country where the proposed program is offered;

e) the faculty teaching in the program must hold qualifications comparable to faculty teaching similar courses on the NDSU campus;

f) the full cost of implementing the proposed program must be recovered;

g) the budget must include provision for reinvestment of some portion of income to promote faculty and staff development and student exchange and demonstrate benefit to the global community.

* This is a draft document and is adapted (with permission) from a similar document from the University at Buffalo, NY.

\section{Twinning Program in India}

NDSU has partnered with the Ansal Institute of Technology (AIT), Gurgaon (near New Delhi), India, in offering a "Twinning" program of study beginning fall 2004. AIT offers a three-year (six-semester) undergraduate (UG) advanced diploma program modeled after the U.S. education system. It also offers bachelor's and master's degree programs in business administration and computer science, and bachelor's degree programs in engineering.

The twinning program prepares students at AIT for a period of one to three years in selected disciplines, based on the curriculum approved by NDSU. The qualified students can then transfer to NDSU to complete the program and receive an NDSU degree. At present, the selected disciplines are BS in Computer\& Electrical Engineering, BS in Computer Science, BS in Business Administration, BS in Biotechnology, and MBA. A brief description of the BS and MBA twinning programs is given in the next two paragraphs.

BS Programs: After successful completion of the six-semester Advanced Diploma program at AIT, selected students will be accepted for transfer to NDSU. In most cases, the students transferred in fall semester should be able to complete NDSU's baccalaureate program within two semesters after coming to NDSU. If students continue making good progress at NDSU in their senior year and are interested in pursuing graduate studies, they can apply to graduate school and will be considered for financial support that typically includes an assistantship and a full tuition waiver. In principle, it is possible for a student joining the twinning program at AIT to complete the UG and postgraduate (PG) degrees awarded by NDSU in 4 years. The student takes 6 semesters in 2 years at AIT and 2 semesters in 9 months at NDSU for a BS degree. The 
student then takes 4 semesters in 15 months at NDSU for the PG degree. The TOEFL will be required for students transferring from AIT to NDSU.

The MBA Program: After successful completion of the one-year postgraduate diploma program at AIT, selected students will be accepted for transfer to NDSU. Students who meet and are accepted under the admission requirements can normally complete the degree requirements in 2 semesters (fall and spring semesters). At the postgraduate diploma level of studies at AIT (that is, during one additional year of studies after bachelor's level education) a minimum cumulative GPA (CGPA) of 3.0 is required for a transfer to the NDSU Graduate School. A maximum of 9 credit hours of graduate work completed at AIT can be transferred to NDSU (corresponding to pre-approved NDSU courses applicable to either the MBA or M.S. program in the relevant discipline). The equivalent grade of $\mathbf{B}$ or better must be earned in each course from AIT to be awarded transfer credit. GRE/GMAT/TOEFL scores as per the departmental requirement will also be needed for students transferring from AIT to pursue graduate studies at NDSU.

Under the "Twinning" arrangement, NDSU will review and approve all core curriculum course offerings in the AIT-NDSU program to ensure that the courses taught at AIT are parallel ("Twinned") in content and structure to the courses taught at NDSU. Only the courses approved by NDSU can be transferred to NDSU. The review includes, but is not necessarily limited to, (a) the overall course composition of the AIT-NDSU Program, (b) the content and related syllabi for each course which is part of the AIT-NDSU Program, (c) texts and other teaching materials appropriate to each course, and (d) qualifications of instructors planning to teach the AIT-NDSU courses.

This program will also allow NDSU students to spend one or more semesters at AIT. These students will be able to take the same courses as normally offered at NDSU, along with AIT students. They will also be able to take courses in Indian history, languages, and culture, attend cultural events, and visit places of interest. The program is designed to promote faculty exchange between the two institutions.

In the Fall of 2004, the program in India was fully subscribed (about 70 students) in Computer \& Electrical Engineering, Computer Science, and Biotechnology at the BS level, and in the MBA program at the master's level. In the future, NDSU plans to expand the number of disciplines and also open off-campuses in India, Dubai, and other countries.

The Indian government has allowed foreign universities to operate in India or form partnerships with existing Indian universities. In a recent interview by the Times of India Newspaper, ${ }^{4}$ the chairman of the University Grant Commission of India was asked, "Is anything being done to regulate the entry of foreign universities into India?" He replied, "This is being already done at the government level and we are a party to it as well; AICTE (All Indian Council for Technical Education) has a stake in it too. I think, soon we will have policy-level guidelines related to foreign universities which are functioning and wanting to function in India. But, one thing is clear; these foreign universities should subject themselves to the assessment and accreditation processes of the countries they belong to and must publicize this information, before they operate in India." 
Industrial partnerships are very important in such a project. An industrial advisory board has been set-up for the NDSU-India project, and senior officials from 3M, GM, John Deere, and Microsoft have already agreed to serve on the board. These organizations can provide scholarships and internships to students to enrich their educational experience and ability to work in a global environment. Such partnerships can prove beneficial to everyone involved and to the global society as a whole.

\section{Innovative Educational Programs}

The educational programs at the off-campus site should be unique and innovative and should be based on the latest research on education. One such program, "A Caring Community of Leaders and Problem-Solvers (CCLP)," has already been started at NDSU and was selected for presentation at the American Association for Higher Education Conference in April 2004. This learner-centered and experiential program involves real-life projects, civic engagement, transformational leadership development, advanced technology, and teamwork. Inspiration, innovation, empowerment, inquiry, and life-long learning are fostered and are an integral part of the curriculum design. Such pedagogies are absolutely essential in the global economy, because they prepare students who can start contributing quickly at their work places, as well as in the society. The CCLP program is described below.

The CCLP program integrates problem-based learning techniques, service learning, and leadership training into undergraduate first-year English and speech classes that are attended by cohorts of about twenty-five students each. The program also includes a strong residential component, mentoring from upper-class students, and social functions with students, mentors, instructors, advisors, and other CCLP team members at the beginning and middle of each semester. In addition, biweekly luncheon workshops on developing leadership, team building, and problem-solving skills are organized.

The learning community program at NDSU has improved student retention, GPA, leadership development, and civic engagement. It has met the goals established by the program from the beginning. For instance, students become members of a small community, within the larger university context, by living in close proximity to one another and attending some of the same core courses. They participate in classroom learning experiences that utilize problem-based learning techniques, leadership development, and service learning projects. Students meet regularly with mentors and faculty to discuss issues that are important to them. Through this process, students become actively engaged as learners and as responsible members of their campus and local community.

\section{Conclusions}

Universities and colleges in the 21 st century will need to adopt an educational paradigm where interdependence and interconnectedness among the world's people become the norm. Several universities like the University of Rhode Island, MIT, the University at Buffalo, Texas A\&M University, and Georgia Tech have large international programs or off campuses in countries like France, Germany, Singapore, Qatar, and China. This paper provides details of a new Indian project that has been started at North Dakota State University (NDSU) to promote international 
collaboration and activities. An industrial advisory board with members from multi-national companies like 3M, GM, John Deere, and Microsoft has been formed. It can prove beneficial to everyone involved and to the global society as a whole. Finally, inspiration, innovation, empowerment, inquiry, and life-long learning should be an integral part of any academic (especially international) program. Such pedagogies are absolutely essential in the global economy, because they prepare students who can start contributing quickly at their work places, as well as in the global society.

\section{Acknowledgement}

The authors thank Dr. Richard Shaw and his colleagues in the Center for Writers at North Dakota State University for their help in the preparation of this manuscript and proof reading.

\section{References}

1. NASULGC, (2004). “A Call to Leadership: The Presidential Role in Internationalizing the University,” A Report of the NASULGC Task Force on International Education, $<$ http://www.nasulgc.org/CIP/Task\%20Force/Call to leadership.pdf>, accessed on December 27, 2004.

2. AACU, (2004). "Shared Futures: Global Learning and Social Responsibility," An Initiative of ACCU, < http://www.aacu.org/SharedFutures/>, accessed on December 27, 2004.

3. Gates, R. M., (2003). "Open Doors Versus Closed Borders: The Challenge for Universities,“ A speech given at the convention of National Association of State Universities and Land-Grant Colleges, $<$ http://international.tamu.edu/gatesoped.htm|\#2>, accessed on November 18, 2003.

4. Times of India, (2004). “UGC Steps up Quality Campaign,” An Interview with UGC Chairman, $<$ http://timesofindia.indiatimes.com/articleshow/972046.cms>. accessed on December 27, 2004.

\section{Biography}

SUDHIR MEHTA, Ph.D. is a professor of Mechanical Engineering at North Dakota State University (NDSU). He received numerous awards from the NDSU and professional societies, including the ASEE, and several grants from the NSF, 3M, and HP to enhance engineering education. He is a Fellow Member of the ASEE, and co-author of the courseware, "Statics: The Next Generation," which is electronically published by Prentice-Hall in August 2001.

ZHIFENG KOU is a Ph.D. candidate in Mechanical Engineering and a Master degree student in Computer Science at North Dakota State University. His research interests are biomechanics of head/neck injury, bioinstrumentation, neuro-engineering, medical informatics, telemedicine and e-health, and engineering education. He is a student member of the ASEE and authored various journal and conference papers in his concentration areas. 